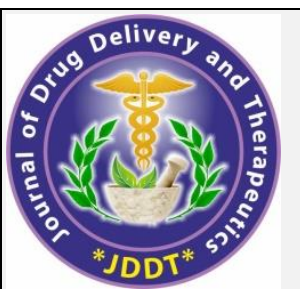

open 1 Access
Available online on 15.12 .2020 at http://jddtonline.info

\section{Journal of Drug Delivery and Therapeutics}

Open Access to Pharmaceutical and Medical Research

(C) 2011-20, publisher and licensee JDDT, This is an Open Access article which permits unrestricted non-commercial use (CC By-NC), provided the original work is properly cited

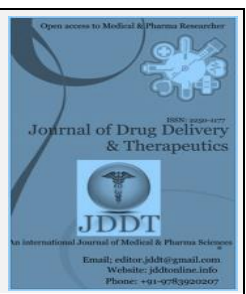

Research Paper

\title{
The Hepatoprotector Effect of Uncaria gambir Roxb Extract in Wistar Rats Induced by Paracetamol
}

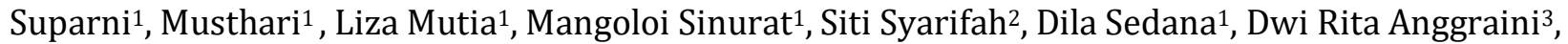 \\ Muhammad Ichwan²* \\ 1 Department of Medical Laboratory Technology, Polytechnic Health Ministry of Health Medan, Jl. Williem Iskandar Psr V barat no.6 Medan \\ 20731, Indonesia \\ 2 Department of Pharmacology and Therapeutics, Faculty of Medicine, University of Sumatera Utara Jl. Dr. Mansur Kampus USU Medan 20155, \\ Indonesia \\ ${ }^{3}$ Department of Anatomy, Faculty of Medicine, University of Sumatera Utara Jl. Dr. Mansur Kampus USU Medan 20155, Indonesia
}

\section{Abstract}

Background: Drug induced liver injury (DILI) is known as the damage of liver cells due to chronic administrations of drug. The chronic administration of paracetamol could be trigger the damage of liver cells. The hepatoprotector agents are still limited worldwide. Gambier(Uncaria gambir Roxb) is an Indonesia'traditional medicine which have many benefits as antioxidant, antiseptic, antidiarrhoea, etc that commonly used in society.

Method: The present study was conducted to investigate the hepatoprotector effect ofgambier in wistar rats induced by paracetamol. The wistar rats were divided into seven groups and received the treatment orally for 12 days. Group I (aquadest), II(curcuma,400 mg/kgBW),III (gambier,26 mg/200gr), IV(gambier, $53 \mathrm{mg} / 200 \mathrm{gr}$ ), V(gambier,106 mg/200gr),VI(gambier,212 mg/200gr) and VII(gambier,424mg/200gr). Termination, blood and liver organ collection were done after all group induced by paracetamol for two days. Histopatology changes of liver were examined using Hematoxycilline (HE) staining. AST and ALT levels were analyzed.

Results: There were significant differentiation of AST levels among the groups, especially between group I and group IV and between group II and group IV. The ALT levels were statistically significant between group II and group V using Mann-Whitney test (p<0,05). In histopatology examination, there were significant differentiation between group I with another group, not only group II but also group III-VII (p<0,05). In the treatment group, group III and IV had been showed the improvement of liver cells damage than group I by using One-way Annova, post hoc Bonferroni $(\mathrm{p}<0,05)$.

Conclusion: Uncaria gambir Roxb has hepatoprotector activity start at dose $53 \mathrm{mg} / 200 \mathrm{grBWin}$ rats. The hepatoprotector activity was not superior than curcuma.

Keywords: hepatoprotector, Uncaria gambir Roxb, AST,ALT,histopatology

Article Info: Received 020ct 2020; $\quad$ Review Completed 19 Nov 2020; $\quad$ Accepted 30 Nov 2020; Available online 15 Dec 2020

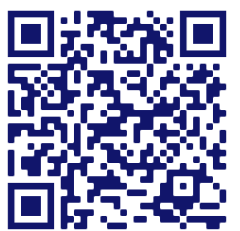

Cite this article as:

Suparni, Musthari, Mutia L, Sinurat M, Syarifah S, Sedana D, Anggraini DR, Ichwan M, The Hepatoprotector Effect of Uncaria gambir Roxb Extract in Wistar Rats Induced by Paracetamol, Journal of Drug Delivery and Therapeutics. 2020; 10(6-s):61-66 http://dx.doi.org/10.22270/jddt.v10i6-s.4457

*Address for Correspondence:

Muhammad Ichwan, Department of Pharmacology and Therapeutics, Faculty of Medicine, University of Sumatera Utara Jl. Dr. Mansur Kampus USU Medan 20155, Indonesia

\section{INTRODUCTION}

The incidences of liver injury worldwide and in Indonesia are steadily increasing over the years. There were two billion people suffering of Hepatitis B worldwide, 170 people get hepatitis $\mathrm{C}$ and 1,5 million were die due to hepatitis every year ${ }^{1}$. In Indonesia, there were $38,2 \%$ cases of hepatitis in the hospital located in Tangerang 2 . There are several factors which induce liver injury such as viral infection, alcohol and chronic administration of drugs ${ }^{3}$. Drug induced liver injury (DILI) are commonly caused by rifampisin, isoniazid, ceftriaxon and analgetic drug, paracetamol. Previous study showed $35 \%$ of 100 patients underwent DILI ${ }^{4}$.
Paracetamol has been already known as the popular analgetic drug due to wide therapeutic index and the potency to treat mild-moderate pain in several diseases,nevertheless the hepatotoxic effect are increasing in chronic and large doses administration of paracetamol 5 . The availability of hepatoprotector drugs to prevent DILI was still limited to Curcuma 6.

In Indonesia, especially North Sumatera, gambir (Uncaria gambir Roxb) is the traditional medicine widely used for diarrhoea, dysentery, gargle for throat sore etc. Prior studies analyzed the effect of antihyperlipidemia and antiaterosclerosis of this traditional medicine 7 . The 
antioxidant activity usually induced by catechin in gambir. The usage of gambir is common in North Sumatera but there were limited data showed the efficacy of gambir as hepatoprotector ${ }^{8-9}$.

\section{MATERIALS AND METHODS}

This research is experimental study with post-test only design. The study was conducted during March to October 2019 and has been approved by Health Research Ethics Committee Polytechnic Health Ministry Of Health Medan No.337/KEPK Poltekkes Kemenkes Medan/2019

\section{Materials}

Our study used gambier which is an herbal medicine contain catechins as antioxidant. We used gambier (Uncaria gambir Roxb) in powder form, product by Toyo Brother®, Batch No: 0133517, branded name "Sari Uncaria). The composition of " Sari Uncaria" were consisted of water $(3,22 \%)$, tannin $(21,48 \%)$, catechine $(81,37 \%)$. The composition analyze process were done in Nature Organic Chemistry Lab, Chemistry Dept, Institut Teknologi Bandung 10. We also used paracetamol tablet (Dexa Medica), curcuma tablet (Dexa Medica), aquadest and rats pellets.

\section{Animals}

Male healthy Wistar rats (Rattus norvegicus) with fulfilled inclusion criteria in this study,i.e.,150-200 g BW, age 2-3 months, were obtained from animal house of Universitas Sumatera Utara. The aggressive and sick/died rats were excluded from this study.

\section{Experimental design}

The animals were divided randomly into seven groups of eight rats each and treated as follows:

1. Group I (NC): negative control rats (standard pellets and water ad-libitum) for 14 days

2. Group II (PC): positive control, rats were administered with $400 \mathrm{mg} / \mathrm{kg}$ of curcuma, standard pellets, and water ad libitum for 14 days.
3. Group III (P1): ): Rats were administered with $26 \mathrm{mg} / 200 \mathrm{grBB}$ of gambier, standard pellets, and water ad libitum for 14 days.

4. Group IV (P2): Rats were administered with 53 $\mathrm{mg} / 200 \mathrm{grBB}$ of gambier, standard pellets, and water ad libitum for 14 days.

5. Group V (P3): Rats were administered with $106 \mathrm{mg} / 200 \mathrm{grBB}$ of gambier, standard pellets, and water $a d$ libitum for 14 days

6. Group VI (P4): Rats were administered with 212 $\mathrm{mg} / 200 \mathrm{grBB}$ of gambier, standard pellets, and water ad libitum for 14 days

7. Group VII (P5): Rats were administered with 424 $\mathrm{mg} / 200 \mathrm{grBB}$ of gambier, standard pellets, and water ad libitum for 14 days.

All the groups were administered paracetamol with dose 1 gr/kgBW in day 13-14. Animal termination and extraction of blood and liver samples were done in Pharmacology Lab, Dept.of Pharmacology, Universitas Sumatera Utara. The histopatology of liver were examined by using Hematoxycilin-Eosin (HE) Staining and ALT/AST were analyzed by using the photometric method.The histopatology of liver was analyzed using scoring HE index. Scoring were determined based on microscopis examination. The liver cells were divided into three category:steatosis cells, ballooning cells and inflammation cells.

Data were analysed with Kruskall Wallis, Mann Whitney, One-Way Annova and post hoc Bonferroni test using IBM SPSS Statistic 21.

\section{RESULTS}

\subsection{Differentiation of AST values}

In our study, there was differentiation of AST values among the groups (Kruskal-wallis test). Data was showed in table 1:

Table1. Differentiation of AST values

\begin{tabular}{cccc}
\hline No & Groups & Median (Min-Max) & p \\
\hline $\mathbf{1 .}$ & NC & $137,2(65-218)$ & $0,039 \mathrm{a}$ \\
$\mathbf{2 .}$ & PC & $91,0(70-291)$ & \\
$\mathbf{3 .}$ & P1 & $96,2(47-146)$ & $0,0161,4, \mathrm{~b}$ \\
$\mathbf{4 .}$ & P2 & $57,4(50-66)$ & $0,0092,4, \mathrm{~b}$ \\
$\mathbf{5 .}$ & P3 & $122,6(110-138)$ & \\
$\mathbf{6}$ & P4 & $118,2(89-138)$ & \\
$\mathbf{7}$ & P5 & $109,2(98-130)$ & \\
\hline
\end{tabular}

Based on table.1, there was a significant differentiation of AST values between NC group and P1 group (Mann-whitney test, $\mathrm{p}<0.05)$. The AST values were lowest in P2 group. This data showed, the administration of gambir $(53 \mathrm{mg} / 200$ grBW) had an effect to protect the liver from cell's destruction due to paracetamol induction. Our study also showed a significant differentiation of AST values between NC group and P2 group ( $\mathrm{p}<0.05)$. A lower AST of P2 group compared to PC group indicated the effect of gambir (53 $\mathrm{mg} / 200 \mathrm{grBW}$ ) was stronger to protect the liver cells than curcuma $(\mathrm{p}<0,05)$.

\subsection{Differentiation of ALT values}

There was a significant differentiation of ALT values among the groups $(p<0.05)$. Data was shown in table. 2 below

Table 2: Differentiation of ALT values

\begin{tabular}{llll}
\hline No & Groups & Median (Min-Max) & $\mathrm{p}$ \\
\hline $\mathbf{1 .}$ & NC & $84(60-109)$ & $0,026^{\mathrm{a}}$ \\
$\mathbf{2 .}$ & PC & $81(69-132)$ & \\
$\mathbf{3 .}$ & P1 & $102(93-283)$ & $0,0472,5, \mathrm{~b}$ \\
$\mathbf{4 .}$ & P2 & $107(67-138)$ & \\
$\mathbf{5 .}$ & P3 & $60(54-85)$ & \\
$\mathbf{6}$ & P4 & $71(59-78)$ & \\
$\mathbf{7}$ & P5 & $67(47-109)$ &
\end{tabular}


Based on table 2, there was no significant differentiation of ALT values in NC group compared to PC and gambir group in all doses, but we found a significant differentiation of ALT values between PC group and P3 group (106 mg/200grBW) $(\mathrm{p}<0.05)$. Our data showed there was no significant increasing level of ALT for each groups after induced by paracetamol.

\subsection{Histopathology of Liver Cells}

We analyzed the histopathology of liver cells by Haematoxicilin-Eosin Scoring Index system. Scoring was determined by microscopic examination in pada 10 lapangan pandang dengan menggunakan lensa perbesaran $10 \times 40$. Scoring was counted depend on mean total of destroying liver cells. The classification of destroying liver cell consisted of three category, which were steatosis cell (score 0-3), ballooning cell (score 0-3) and inflammation cell (score 0-3). The final scoring of destroying liver cells were counted based on the mean of steatosis, ballooning and inflammation cells score. The lower the score, indicated less destroying liver cells and higher the score showed the contrary result. The figure 1 showed the scoring of liver cells destruction among the group:

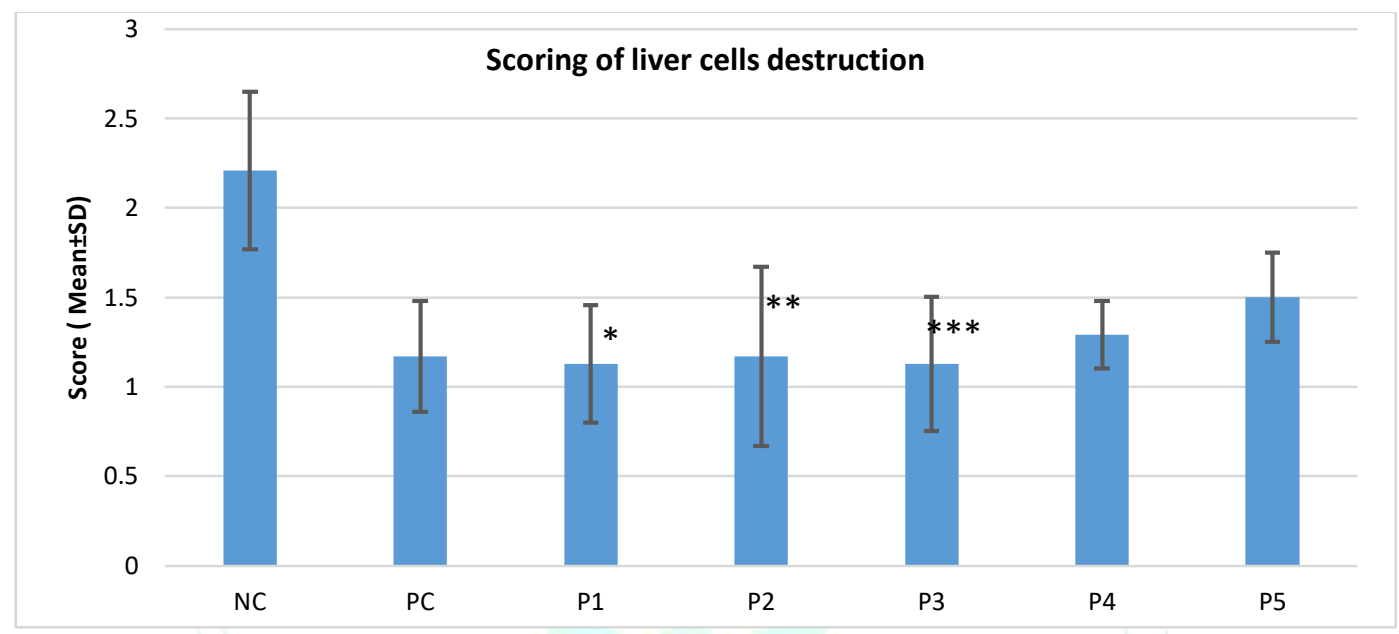

Figure 1: Scoring of liver cells destruction. Values are Mean $\pm \mathrm{SD},{ }^{* * * * * * *} \mathbf{p}<0,05$ vs negative control

Based on figure I, the highest scoring was NC group while PC, P1-P5 groups had lower score. This result indicated PC, P1P5 group had effect to protect the liver (hepatoprotector) which induced by paracetamol. There was a significant differentiation of scoring among the groups $(p<0.05$, OneWay Annova). We did the post-hoc test Bonferroni to analyze which groups had a significant differentiation scoring. Statistical analysis showed there was significant differentiation of scoring between NC groups with PC, P1-P5 groups $(\mathrm{p}<0.05)$ but there was no differentiation of scoring between PC and gambir (P1-P5) groups $((\mathrm{p}>0.05)$. In gambir groups, P1 $(26 \mathrm{mg} / \mathrm{kgBW}$ had showed the significant effect as hepatoprotector than $\mathrm{NC}$, followed by P2-P5 $(\mathrm{p}<0.05)$. Nevertheless, data showed gambir (P1-P5) were not superior than NC group (curcuma).In histopatology liver cells examination by Haematoxicillin staining, we found all of steatosis, ballooning and inflammation cells in NC group (figure 2)

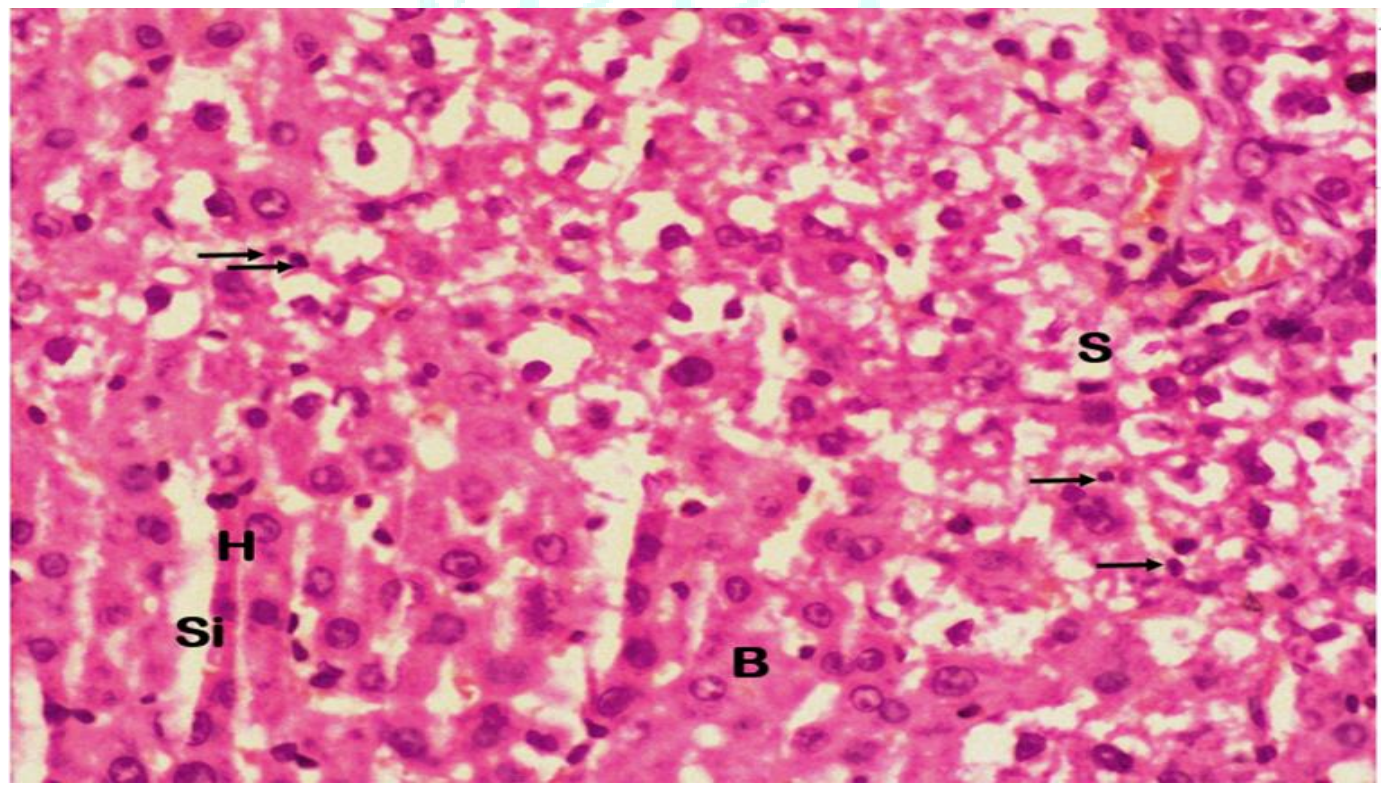

Figure 2: Histopatology liver cells in NC group. (Microscopic 400x), H= hepatosit $\mathrm{Si}=$ sinusoid $\mathrm{B}=\mathrm{Balloning} \mathrm{S}=\mathrm{Steatosis}$ Arrow= limfosit (inflammation cells) 
In PC group, we also found steatosis, ballooning and inflammation cells (figure 3) while in P1 and P2 group, we only found steatosis cells, there were no inflammation and ballooning cells (figure 4).

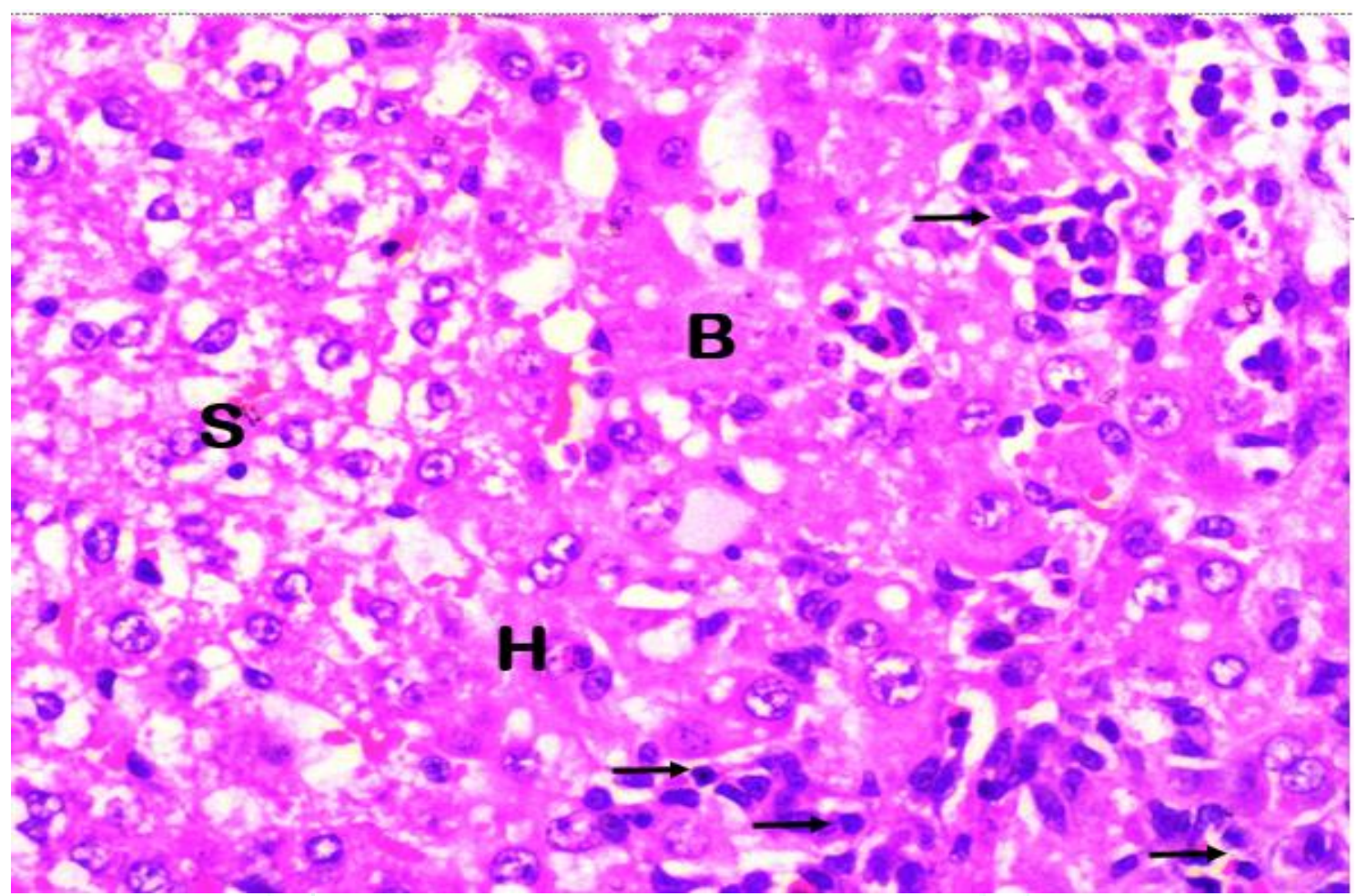

Figure 3: Histopatology liver cells in PC group. (microscopic 400x), H= hepatosit $\mathrm{Si}=$ sinusoid $B=B$ alloning $S=S t e a t o s i s$ Arrow= limfosit (inflammation cells)

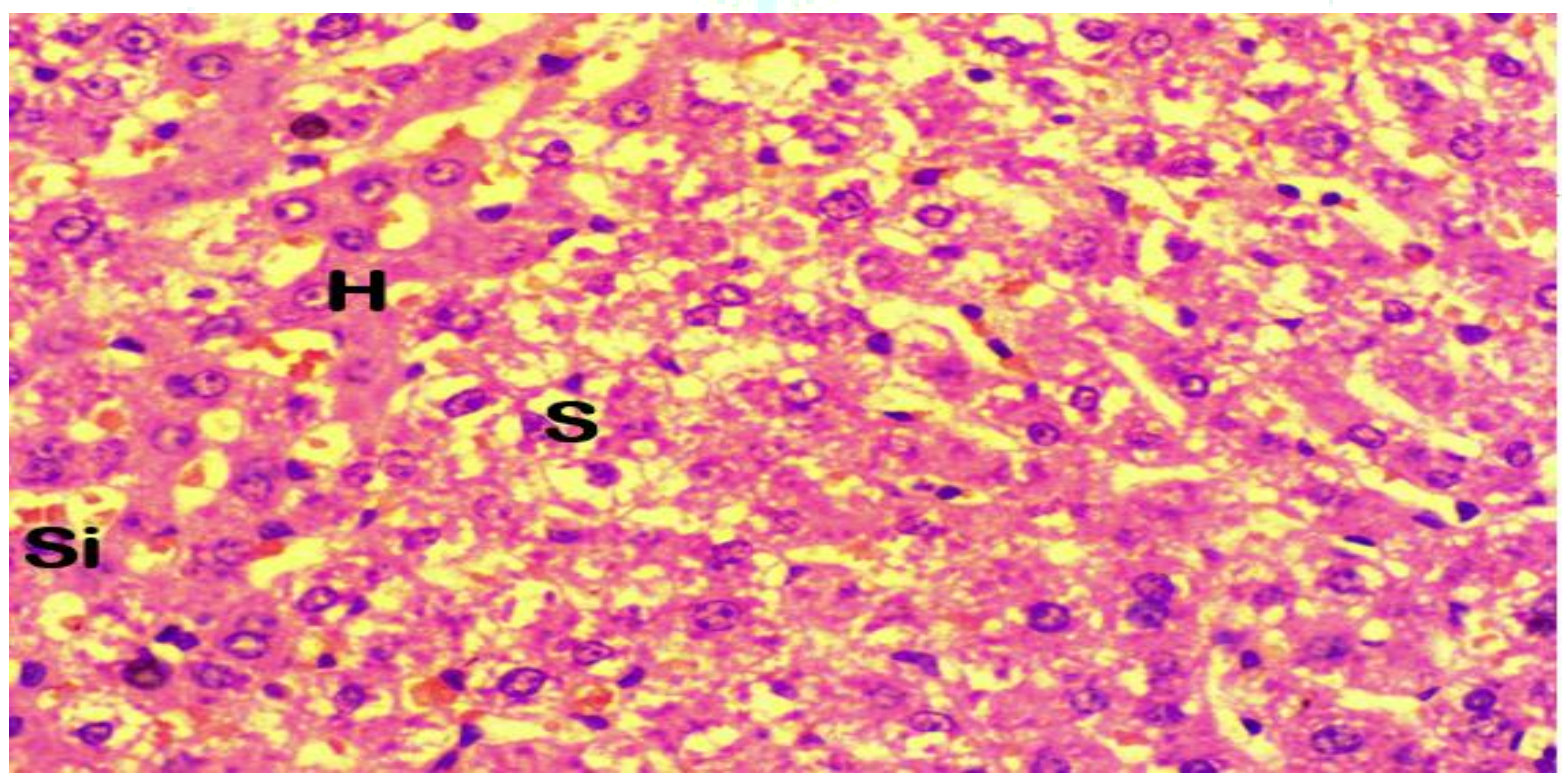

Figure 4: Histopatology liver cells in P1, P2 group.(Microscopic, 400x) H=hepatosit, $\quad S=$ steatosis, $\quad$ Si=sinusoid

\section{DISCUSSION}

In testing the efficacy of Uncaria gambir as a hepatoprotector, liver function was destroyed by induction of paracetamol. The mechanism of liver damage by paracetamol is the formation of a toxic metabolite called $\mathrm{N}$ acetyl-p-benzoquinoneimine (NAPQI).This NAPQI compound has hepatotoxic effect on the liver. In normal conditions, NAPQI can be bound by gluthatione in the body into mercapturate compounds so that it is non-toxic, but in high doses, NAPQI can deplete glutathione reserves in hepatocytes and bind to liver's mitochondria so that oxidative stress can occur in the liver. Continuous oxidative stress can cause injury, apoptosis or necrosis in hepatocytes $11-12$

In this study, we analyzed the effect of Uncaria gambir on the activity of AST and ALT with different doses.The result showed there was a decrease in the value of AST in gambir administration of 53mg / 200grBW dose compared to the negative control group and positive control group that received curcuma while we increased the dose of Uncaria gambir, there was no significant decrease in AST value. This 
study indicated that at higher doses of Uncaria gambir, the hepatoprotector activity was reduced.

There was no significant difference for the ALT value among the groups although there was significant difference of ALT values between PC and P3 group. The AST measurement is the most sensitive assay for assessing liver cell injury, whereas an increase in ALT is sensitive for heart failure 13 . AST enzymes are more abundant in the mitochondria compared to cytoplasm, whereas ALT enzymes are more abundant in the cytoplasm, in further or chronic damage, the mitochondrial membrane emits more AST $^{14}$

It is commonly recognized that DILI is mediated by two chief mechanism: intrinsic and idiosyncratic hepatotoxicity. Intrinsic hepatotoxicity is caused by some drugs include paracetamol which cause liver damage directly by its metabolite 15. Paracetamol can induced acute liver failure (ALF), in morphological features, we can see necrosis with little or no inflammation, ballooning degeneration of hepatocytes which is a form of liver parenchymal celldeath. Necrosis can be accompanied by steatosis ${ }^{16-17}$. In our study, we found all three morphological features, which are ballooning, inflammation and steatosis cells in negative control group, it proved the paracetamol induction caused acute liver failure. In positive control group and treatment group, we also found all of three cells in less amount. Surprisingly, we didn't find the inflammation and ballooning cells in P1 (26 mg/200grBW) and P2 (53 mg/200grBW). This present study showed gambier has an effect to protect the liver cells by induction of paracetamol.

The decrease in liver damage in rats given Uncaria gambir occurs because it has catechins as antioxidants. Catechins are able to neutralize free radicals, and also able to increase other antioxidants in the body such as Gluthation STransferase. This antioxidant is capable to protect liver cells from free radicals produced during the metabolic process of paracetamol into NAPQI. NAPQI is a toxic metabolite which can be detoxified by gluthatione S-transferase to a mercapturate compound but in a toxic dose NAPQI will use up the glutathione S-Transferase reserve in hepatocytes 18-19. Catechin is also known to have antioxidant effects by scavenge superoxide and pro-oxidant effects through cytochrome P450 2E1 (CYP 2E1) 20. CYP2E1 is an enzyme that plays a role in the bioactivation of paracetamol. CYP2E1 participates in the formation of ROS such as superoxide and hydrogen peroxide. ROS can mediate the toxic effects of xenobiotics. Paracetamol knockout mice were found to be less toxic than normal mice 21 . Eventhough catechin also has a pro-oxidant effect, but catechins in gambier are a polyphenolic component that is associated with various health benefits, both in vitro, in vivo and kinis. The characteristics of this therapy are related to the effect of cathecin as a high antioxidant and the effect of free radical scavenging 22 .

Our study is relevant to previous studies which showed that the administration of gambir leaves extract was able to reduce CCL4 induced liver fibrosis in rats ${ }^{9}$. This is also in line with other studies of gambier extract using Carbon tetrachloride (CCL4) as an inducer of liver cell damage, showed that gambier has a hepatoprotector effect by significantly reduceAST and ALT activity, as well as being able to reduce the body weight ratio of mice 8 . In our study, we found the effective dose of gambier is $53 \mathrm{mg} / 200 \mathrm{grBW}$ as hepatoprotector since the administration of $53 \mathrm{mg} / 200 \mathrm{gr}$ BW could lower AST and protect the liver cells by only steatosis cells appeared in histolopatology examination.

This present study showed no superior than curcuma as hepatorotector. Meanwhile, there was a significant differentiation of AST values, but there was no significant differentiation in histopathology examination. Previous studies showed curcuma already has an hepatoprotector effect $23-25$.

\section{CONCLUSION}

Uncaria gambir Roxb have hepatoprotector activity at dose $53 \mathrm{mg} / 200 \mathrm{grBW}$. The hepatoprotector activity was not superior than curcuma.

\section{ACKNOWLEDGMENTS}

The authors are especially grateful to Polytechnic Health Ministry of Health Medan for providing a grant for this study. The research work was supported by BOPTN Polytechnic Health Ministry of Health Medan Grant Scheme 2019 (LB.01.02/01/0805/2019).

\section{REFERENCES}

1. Kemenkes RI. Pusat Data dan Informasi Kementerian Kesehatan RI: Situasi dan Analisis Hepatitis, Kementerian Kesehatan RI, Jakarta Selatan, 2014.

2. Ningrum VDA, Megasari A, Hanifah S.Hepatotoksisitas pada pengobatan tuberkulosis di RSUD Tangerang-Indonesia. J. Ilmiah Farm. UII; 2010; 7(1):39-52.

3. Sonderup, MW. Drug Induced Liver Injury is a Significant Cause of Liver. Drug Induced Liver Injuries; 2006; 29(6).

4. Hikmah EN.. Penggunaan Obat-Obatan Penginduksi Hati Terhadap Pasien Gangguan Fungsi Hati di RSUD Dr.Moewardi Tahun 2013. Fakultas Farmasi Universitas Muhammadiyah Surakarta. 2014

5. Katzung BG. Farmakologi dasar dan klinik. Jakarta; EGC; $10^{\text {th }}$ ed. 2010; 479-489

6. Kusuma, Mahardian A. Efek hepatoprotif kurkumin dan beberapa analognya terhadap ketoksikan parasetamol pada tikus wistar jantan. Tesis. S2 Farmasi Universitas Gajah Mada.2008

7. Yunarto N, Elya B, Konadi L.. Potensi fraksi etil asetat ekstrak daun gambir (Uncaria gambir roxb.) sebagai antihiperlipidemia. Jurnal Kefarmasian Indonesia.; 2015; 5(1):1-10

8. Ningsih Sri et al. Evaluation of Antilipid Peroxidation Activity of Gambir Extract on Liver Homogenat In Vitro. International Journal of PharmTech Research.;2014; 6(3):982-989

9. Fahrudin F et al. Efektifitas Ekstrak Daun Gambir (Uncaria gambir (Hunter) Roxb.) Sebagai Hepatoprotektor Pada Tikus (Rattus norvegicus L.) Yang Diinduksi CCL4. Institut Pertanian Bogor. 2015

10. Pane Ys, Ganie Ra, Lindarto D, Lelo A. The Effect Of Gambier Extract On The Levels Of Malondialdehyde, Superoxide Dismutase, And Blood Glucose In Type 2 Diabetes Mellitus Patients. Asian Journal of Pharmaceutical and Clinical Research. 2018; 11(10):121-124

11. Singh H, Prakash A, Kalia AN, Majeed ABA.. Synergistic hepatoprotective potential of ethanolic extract of Solanum xanthocarpum and Juniperus communis against paracetamol and azithromycin induced liver injury in rats. Journal of Traditional and Complementary Medicine. 2015; 1-7.

12. Departemen Farmakologi dan Terapeutik FK UI. Farmakologi Dan Terapi, edisi 5, Jakarta, Badan Penerbit FK UI.2007

13. Speicher CE, Smith JW. Pemilihan Uji laboratorium Yang Efektif, diterjemahkan oleh Dr. Joko Suyono, Jakarta.Penerbit Buku kedokteran EGC.1993.

14. Akbar N.. Diagnostik Hepatitis Akut dan Kronis. Jakarta: Bagian Ilmu Penyakit dalam FKUI/RSCM.1995

15. Hanje AJ, Chalasani N. How common is chronic liver disease from acute drug induced liver injury? Gastroenterology 2007; 132:2067-8.

16. Williams R. Changing clinical patterns in acute liver failure. J Hepatol 2003; 39:660-1.

17. Letelier ME, Lopes-Valladares M, Peredo-Silva L, RojasSepuvelda D, Aracena P. Microsomal oxidative damage promoted by acetaminophen metabolism. Toxicol in Vitro. 2011 Oct; 25(7):1310-3.

18. Valcheva-Kuzmanova S. Comparative study of the protective effect of Aronia melanocarpa fruit juice and quercetin in a model of paracetamol-induced hepatotoxicity in rats, J Biomed Clin Res, 2015; 8(2):118-123 
19. Caro A, Davis A, Fobare S, Horan N, Ryan C, Schwab C. Antioxidant and pro-oxidant mechanisms of (+) catechin in microsomal CYP2E1-dependent oxidative stress. Toxicology in Vitro 54. 2018.

20. Shayiq RM, Roberts DW, Rothstein K, Snawder J E, Benson W, Ma $\mathrm{X}$, et al. Repeat exposure to incremental doses of acetaminophen provides protection against acetaminophen-induced lethality in mice: An explanation for high acetaminophen dosage in humans without hepatic injury. Hepatology. 1999; 29(2):451-63.

21. Satoh $T$, Igarashi $M$, Yamada $S$, Takahashi $N$, Watanabe $K$. Inhibitory effect of black tea and its combination with acarbose on small intestinal $\alpha$-glucosidase activity. J Ethnopharmacol 2015; 161:147-55.

22. Hasti, S et al. Uji Aktivitas Hepatoproteksi dan Toksisitas Akut dari Ekstrak Gambir Terstandarisasi. 2012; 34-38.
23. Rachman,F.Uji Hepatoprotektor Ekstrak Metanol Daun Sambiloto (Andrographis panicualata) Terhadap Kadar Malondialdehid Plasma Tikus Putih Jantan Galur Wistar Yang Diinduksi Parasetamol. Fakultas Kedokteran Universitas Tanjung Pura Pontianak. 2015

24. Hadinata, MT. Uji Efek Hepatoprotektor Ekstrak Temulawak Pada Tikus Putih Jantan Galur Wistar Yang Diinduksi Parasetamol. Fakultas Kedokteran Universitas Muhammadiyah Surakarta. 2016.

25. Wibowo,M.et al. The Hepatoprotectoctive Effect of Ethanol Extract of Syzgium campanulatum (Korrth) and syzygium aromaticum (L) Leaf on Male Wistar Rat was induced by Paracetamol. 15; 2:196-202. 